\title{
Fabrication of Carbon Nanotube-Molecule-Silicon Junctions
}

Austen K. Flatt, Bo Chen and James M. Tour*

\section{Supporting Information}

Synthetic Scheme for Compound 2..................................................S1

General Methods for Monolayer Formation and Surface Characterization.............S1

AFM Image of Control Sample..........................................................S3

General Synthetic Methods.............................................................

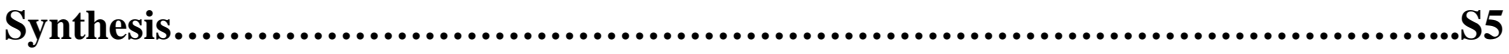

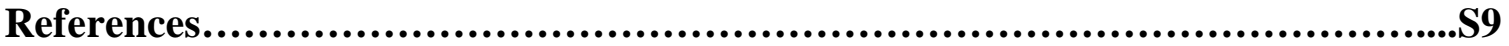

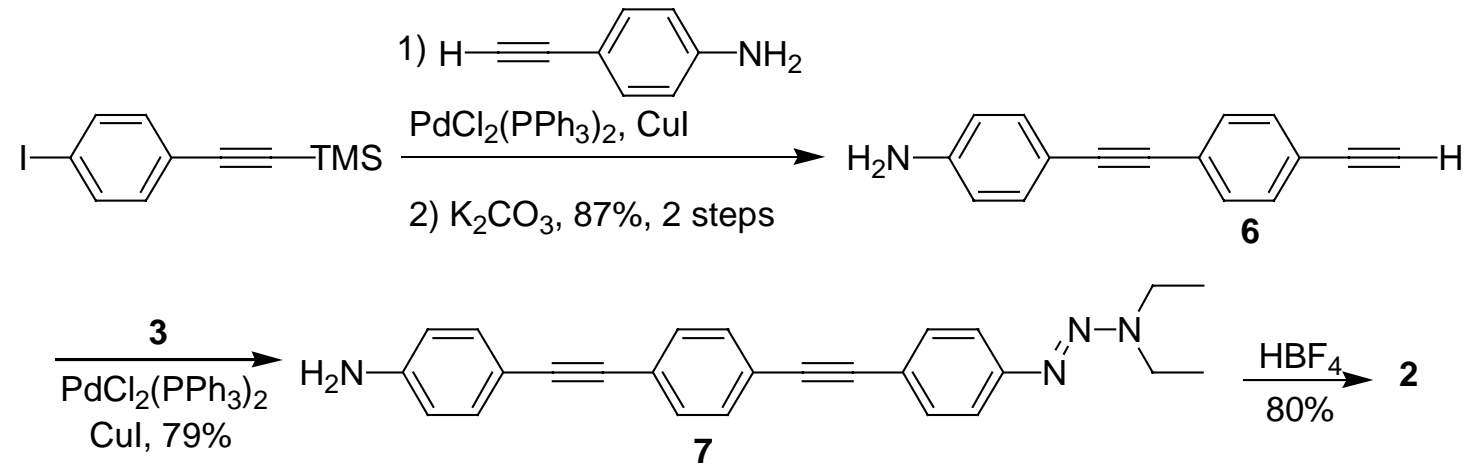

Figure 1. Synthesis of compound 2.

Reagents and Solvents for Surface Characterization. Acetonitrile $\left(\mathrm{CH}_{3} \mathrm{CN}, 99.5+\%\right)$ was purchased from Aldrich and stored in an nitrogen filled glovebox. Reagent grade acetonitrile $\left(\mathrm{CH}_{3} \mathrm{CN}\right)$ and pure water (resistivity $>18 \mathrm{M} \Omega \mathrm{cm}$ ) were used for rinsing. Semi-conductor grade ammonium fluoride $\left(\mathrm{NHF}_{4}\right) 40 \%$ was purchased from Aldrich. Concentrated hydrochloric acid $(\mathrm{HCl})$, concentrated ammonium hydroxide $\left(\mathrm{NH}_{4} \mathrm{OH}\right)$, concentrated sulfuric acid $\left(\mathrm{H}_{2} \mathrm{SO}_{4}\right), 49 \%$ hydrofluoric acid (HF), and 30\% hydrogen peroxide $\left(\mathrm{H}_{2} \mathrm{O}_{2}\right)$ were purchased at reagent grade. 
Ellipsometric Measurements. The film thickness was measured using a single wavelength (632.8 nm laser) Gaertner Strokes ellipsometer. The $n$ and $k$ values were taken for each substrate. The thickness was modeled as a single absorbing layer on the top of an infinitely thick substrate (fixed $\mathrm{n}_{\mathrm{s}}$ ). The observed error for repeat measurements of the same spot was typically less than $0.2 \mathrm{~nm}$.

Atomic Force Microscopy (AFM) Measurements. A Digital Instruments Nanoscope IIIa tapping mode instrument was used to obtain AFM images of SWNTs. The images were taken in air without the use of a purge box and immediately imaged following assembly.

X-ray Photoelectron Spectroscopy (XPS) Measurements. A Quantera XPS Scanning Microprobe was used in collecting the X-ray Photoelectron Spectroscopy (XPS) data, the takeoff angle was $45^{\circ}$, and $114.8 \mathrm{~W}$ monochromatic $\mathrm{Al} \mathrm{X}$-ray source was applied for all the measurements.

Surface Preparation. ${ }^{1} \mathrm{Si}(111)$ shards (prime grade, boron doped) were cleaned in piranha solution $\left(2: 1 \mathrm{H}_{2} \mathrm{SO}_{4}: \mathrm{H}_{2} \mathrm{O}_{2}\right)$ at $100^{\circ} \mathrm{C}$ for $30 \mathrm{~min}$, and rinsed with pure water (resistivity > $18 \mathrm{M} \Omega \mathrm{cm}$ ). The shards were immersed in Ar-sparged $40 \% \mathrm{NH}_{4} \mathrm{~F}$ solution for $15 \mathrm{~min}$ to generate the hydrogen-terminated surface. The shards were rinsed thoroughly with water and dried in a stream of nitrogen gas.

Reactions with Diazonium Salts. ${ }^{1}$ The fresh surfaces were immediately brought into an $\mathrm{N}_{2}$ glovebox. A $0.2 \mathrm{mM}$ solution of $\mathbf{1}$ or $\mathbf{2}$ in anhydrous $\mathrm{CH}_{3} \mathrm{CN}$ was freshly prepared in the glovebox and the hydrogen terminated silicon substrates were immersed in the solution. The reaction vessel was sealed for the desired reaction time. Following assembly, the substrates were removed from the glovebox, rinsed with $\mathrm{CH}_{3} \mathrm{CN}$, and dried 
with $\mathrm{N}_{2}$. The film thickness was immediately measured with by ellipsometry and XPS data was collected.

Attachment of SWNTs. The substrate was removed from the glovebox and placed in a 0.3 M solution of isoamylnitrite in $\mathrm{CH}_{3} \mathrm{CN}$ for 5 min to diazotize the terminal aniline. The substrate was removed and immediately immersed in a sodium dodecylsulfate (SDS)/SWNT suspension ${ }^{2,3}(0.2 \mu \mathrm{M})$ at $\mathrm{pH} 10$ for 3-16 $\mathrm{h}$ (depending on coverage requirements). Following nanotube attachment, the substrate was removed, rinsed with water, $\mathrm{CH}_{3} \mathrm{CN}$ and dried with a stream of nitrogen to afford the desired structure.

\section{AFM Image of Control Sample.}
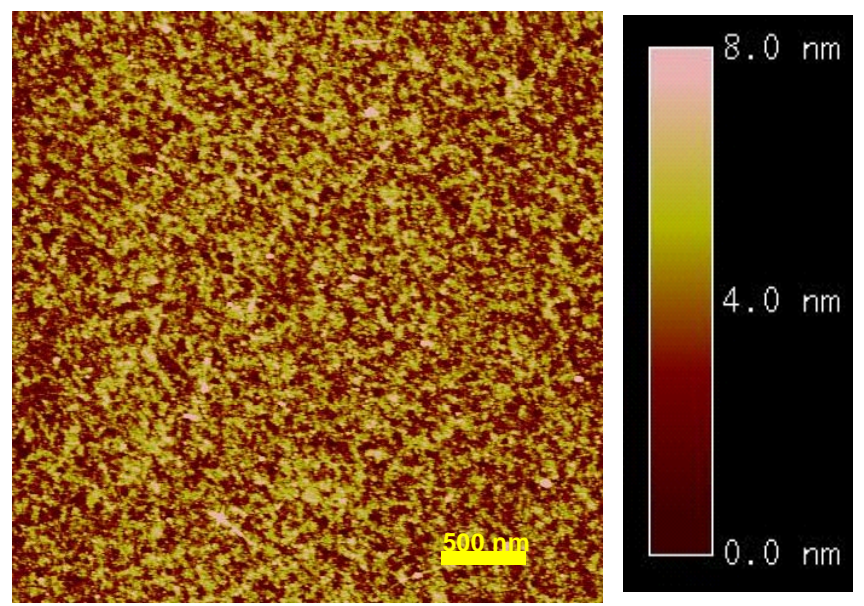

Figure 2. AFM image when the isoamylnitrite diazotization reaction of the terminal aniline is not employed. Few if any SWNTs are seen on the surface.

General Synthetic Methods. Unless stated otherwise, reactions were performed in oven-dried, nitrogen flushed glassware equipped with a magnetic stir bar using freshly distilled solvents. Reagent grade tetrahydrofuran (THF) was distilled from sodium benzophenone ketyl. Triethylamine (TEA) was distilled from calcium hydride. Trimethylsilylacetylene (TMSA) was donated by FAR Research Inc. All other commercially available reagents were used as received. Unless otherwise noted, reactions 
were magnetically stirred and monitored by thin-layer chromatography (TLC) using E. Merck silica gel $60 \mathrm{~F}_{254}$ precoated plates $(0.25-\mathrm{mm})$. Flash chromatography was performed with the indicated solvent systems using silica gel grade 60 (230-400 mesh).

${ }^{1} \mathrm{H}$ and ${ }^{13} \mathrm{C}$ NMR spectra were observed at 400 and $100 \mathrm{MHz}$, respectively, on a Bruker Avance 400 spectrometer. NMR chemical shifts are reported in ppm downfield from tetramethylsilane (TMS). IR spectra were obtained on a Nicolet Avatar 360 FTIR. Mass spectroscopy was performed at the Rice University Mass Spectroscopy Laboratory. Melting point values are uncorrected. All new compounds were named using the Beilstein AutoNom application of Beilstein Commander 2000 software.

General Procedure for the Coupling of a Terminal Alkyne with an Aryl Halide Utilizing a Palladium-Copper Cross-Coupling (Castro-Stephens/Sonogashira Protocol). ${ }^{4}$ To a screw cap tube or a round-bottom flask were added the aryl halide, bis(triphenylphosphine)palladium(II) dichloride (5 mol \% based on aryl halide), and copper(I) iodide (10 mol \% based on aryl halide). The vessel was sealed with a rubber septum, evacuated, and backfilled with nitrogen $(3 \times)$. A cosolvent of THF was added followed by the amine base. The terminal alkyne was then added followed by replacing the septum with a screw cap and the reaction was heated if necessary. TLC was used to follow the progress of the reaction, and when complete, the reaction vessel was cooled to room temperature, and the mixture was quenched with water or a saturated solution of $\mathrm{NH}_{4} \mathrm{Cl}$. The organic layer was diluted with organic solvent and washed with brine $(3 \times)$. The combined aqueous layers were extracted with organic solvent $(3 \times)$, and the combined organic layers were dried over anhydrous $\mathrm{MgSO}_{4}$, the slurry was filtered, and 
the solvent was removed from the filtrate in vacuo, followed by further purification of the residue as indicated.

General Procedure for Alkaline Deprotection of Trimethylsilyl-Protected Alkynes. The TMS-protected alkyne was added to an open round-bottom flask, and a solution of $\mathrm{K}_{2} \mathrm{CO}_{3}$ in $\mathrm{MeOH}$ and $\mathrm{CH}_{2} \mathrm{Cl}_{2}$ was added to dissolve the organic compound. The reaction was quenched with water and extracted with organic solvents $(3 \times)$. The combined organic layers were dried over anhydrous $\mathrm{MgSO}_{4}$, the slurry was filtered, and the solvent was removed from the filtrate in vacuo to provide a crude product for further purification via flash chromatography.

\section{Synthesis}

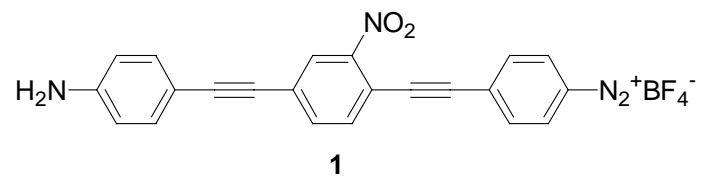

\section{4-[4-(4-Amino-phenylethynyl)-2-nitro-phenylethynyl]-benzenediazonium}

tetrafluoroborate (1). Compound $5(0.10 \mathrm{~g})$ was dissolved in THF $(20 \mathrm{~mL})$. Tetrafluoroboric acid (48\% in water) $(0.20 \mathrm{~mL})$ was added dropwise. The mixture turned red and was stirred for 2 min. $\mathrm{Et}_{2} \mathrm{O}(50 \mathrm{~mL})$ was added and a yellow precipitate formed. The mixture was filtered and washed with excess $\mathrm{Et}_{2} \mathrm{O}$ under a stream of nitrogen gas to afford $1(0.07 \mathrm{~g}, 67 \%)$. FTIR (KBr) 3418, 2819, 2574, 2264, 2211, 1574, 1541, 1513, 1346, 1077, 838, $523 \mathrm{~cm}^{-1} .{ }^{1} \mathrm{H}$ NMR $\left(400 \mathrm{MHz},\left(\mathrm{CD}_{3}\right)_{2} \mathrm{CO}\right) \delta 8.95(\mathrm{~d}, J=9.0 \mathrm{~Hz}, 2 \mathrm{H})$, $8.42(\mathrm{~s}, 1 \mathrm{H}), 8.25(\mathrm{~d}, J=9.0 \mathrm{~Hz}, 2 \mathrm{H}), 8.05(\mathrm{~s}, 2 \mathrm{H}), 7.92(\mathrm{~d}, J=8.6 \mathrm{~Hz}, 2 \mathrm{H}), 7.72(\mathrm{~d}, J=$ $8.6 \mathrm{~Hz}, 2 \mathrm{H})$. Attempts to acquire ${ }^{13} \mathrm{C}$ NMR spectral information were unsuccessful due to the instability of compound $\mathbf{1}$ in solution for extended time periods. 


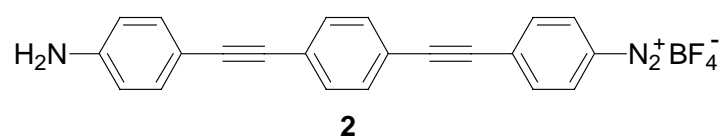

\section{4-[4-(4-Amino-phenylethynyl)-phenylethynyl]-benzenediazonium tetrafluoroborate}

(2). Compound 7 (0.12 g) was dissolved in THF (10 mL). Tetrafluoroboric acid (48\% in water) $(0.20 \mathrm{~mL})$ was added dropwise. The mixture turned red and was stirred for $2 \mathrm{~min}$. $\mathrm{Et}_{2} \mathrm{O}(50 \mathrm{~mL})$ was added and a yellow precipitate formed. The mixture was filtered and washed with excess $\mathrm{Et}_{2} \mathrm{O}$ to afford 2 (0.10 g, 80\%). FTIR (KBr) 3440, 2849, 2576, 2270, $2208,1574,1516,1079,837,523 \mathrm{~cm}^{-1} .{ }^{1} \mathrm{H}$ NMR $\left(500 \mathrm{MHz},\left(\mathrm{CD}_{3}\right)_{2} \mathrm{CO}\right) \delta 8.90(\mathrm{~d}, J=$ $9.1 \mathrm{~Hz}, 2 \mathrm{H}), 8.21(\mathrm{~d}, J=9.1 \mathrm{~Hz}, 2 \mathrm{H}), 7.85(\mathrm{~d}, J=8.7 \mathrm{~Hz}, 2 \mathrm{H}), 7.76(\mathrm{~d}, J=8.5 \mathrm{~Hz}, 2 \mathrm{H})$, $7.72(\mathrm{~d}, J=8.5 \mathrm{~Hz}, 2 \mathrm{H}), 7.69(\mathrm{~d}, J=8.7 \mathrm{~Hz}, 2 \mathrm{H})$. Attempts to acquire ${ }^{13} \mathrm{C}$ NMR spectral information were unsuccessful due to the instability of compound 2 in solution for extended time periods.

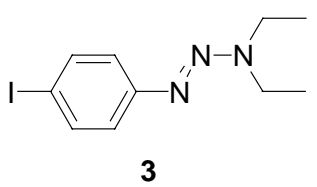

1-(4-Iodophenyl)-3,3-diethyltriazene $(\mathbf{3}){ }^{5}{ }^{5}$ 4-Iodoaniline $(5.00 \mathrm{~g}, 22.83 \mathrm{mmol})$ was added to a $250 \mathrm{~mL}$ round bottom flask. THF $(25 \mathrm{~mL})$ was added and the reaction was cooled to $-30{ }^{\circ} \mathrm{C}$. Borontrifluoride diethyletherate $(11.57 \mathrm{~mL}, 91.32 \mathrm{mmol})$ was added dropwise followed by the dropwise addition of $t$-butylnitrite $(9.50 \mathrm{~mL}, 79.91 \mathrm{mmol})$. The reaction was warmed to room temperature and $\mathrm{Et}_{2} \mathrm{O}(150 \mathrm{~mL})$ was added. The mixture was vacuum filtered and washed with $\mathrm{Et}_{2} \mathrm{O}$ to afford the aryl diazonium salt which was dissolved in $\mathrm{CH}_{3} \mathrm{CN}(80 \mathrm{~mL})$ and cooled to $0{ }^{\circ} \mathrm{C}$. A solution of $\mathrm{H}_{2} \mathrm{O}(40 \mathrm{~mL}), \mathrm{K}_{2} \mathrm{CO}_{3}$ (8.34 g, $60.41 \mathrm{mmol})$, and diethylamine $(4.20 \mathrm{~mL}, 40.27 \mathrm{mmol})$ was added to the reaction 
which turned deep red. The mixture was allowed to warm to room temperature over $3 \mathrm{~h}$ at which point it was poured in $\mathrm{H}_{2} \mathrm{O}$ and extracted $(3 \times)$ with $\mathrm{CH}_{2} \mathrm{Cl}_{2}$, dried using anhydrous $\mathrm{MgSO}_{4}$ and concentrated in vacuo. Column chromatography, silica gel (3:1 $\mathrm{CH}_{2} \mathrm{Cl}_{2}$ /hexane) afforded 3 as a viscous red oil (5.13 g, 74\%). ${ }^{1} \mathrm{H}$ NMR (400 MHz, $\left.\mathrm{CDCl}_{3}\right) \delta 7.65(\mathrm{~d}, J=8.8 \mathrm{~Hz}, 2 \mathrm{H}), 7.19(\mathrm{~d}, J=8.8 \mathrm{~Hz}, 2 \mathrm{H}), 3.79(\mathrm{q}, J=7.1 \mathrm{~Hz}, 4 \mathrm{H}), 1.25$ (s broad, 6H).

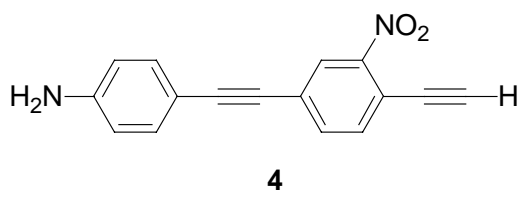

4-(4-Ethynyl-3-nitro-phenylethynyl)-phenylamine (4). ${ }^{6}$ Following the general coupling procedure (4-Iodo-2-nitro-phenylethynyl)-trimethyl-silane ${ }^{7}(1.20 \mathrm{~g}, 3.43 \mathrm{mmol})$ was coupled to 4-ethynyl-phenylamine ${ }^{8}(0.44 \mathrm{~g}, 3.77 \mathrm{mmol})$ using $\mathrm{PdCl}_{2}\left(\mathrm{PPh}_{3}\right)_{2}(0.12 \mathrm{~g}, 0.17$ mmol), CuI (0.06 g, $0.34 \mathrm{mmol})$, TEA $(4 \mathrm{~mL})$, and THF $(20 \mathrm{~mL})$. The reaction was stirred at $40{ }^{\circ} \mathrm{C}$ for 3 days until the starting material was consumed as judges by TLC. The reaction was poured in $\mathrm{H}_{2} \mathrm{O}$ and extracted $(3 \times)$ with $\mathrm{CH}_{2} \mathrm{Cl}_{2}$, dried using anhydrous $\mathrm{MgSO}_{4}$ and concentrated in vacuo. Column chromatography, silica gel $\left(\mathrm{CH}_{2} \mathrm{Cl}_{2}\right)$ afforded the TMS protected alkyne as a yellow solid $(0.87 \mathrm{~g}, 75 \%)$. Following the general deprotection of TMS-protected alkynes, the yellow solid (0.87 g, $2.56 \mathrm{mmol})$ was dissolved in a mixture of $\mathrm{CH}_{2} \mathrm{Cl}_{2}(25 \mathrm{~mL}), \mathrm{MeOH}(25 \mathrm{~mL})$, and $\mathrm{K}_{2} \mathrm{CO}_{3}(1.77 \mathrm{~g}, 12.81$ mmol). The product $\mathbf{4}$, was afforded without addition purification as an orange solid $(0.63 \mathrm{~g}, 92 \%) .{ }^{1} \mathrm{H}$ NMR $\left(400 \mathrm{MHz},\left(\mathrm{CD}_{3}\right)_{2} \mathrm{CO}\right) \delta 8.09(\mathrm{t}, J=1.1 \mathrm{~Hz}, 1 \mathrm{H}), 7.76(\mathrm{~d}, J=1.1$ $\mathrm{Hz}, 2 \mathrm{H}), 7.31(\mathrm{~d}, J=8.7 \mathrm{~Hz}, 2 \mathrm{H}), 6.70(\mathrm{~d}, J=8.7 \mathrm{~Hz}, 2 \mathrm{H}), 5.23(\mathrm{~s}, 2 \mathrm{H}), 4.26(\mathrm{~s}, 1 \mathrm{H})$. 


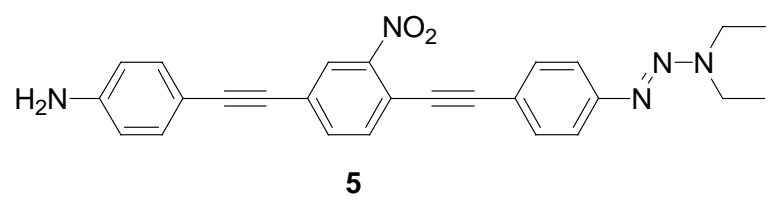

\section{4-\{4-[4-(3,3-Diethyl triazene)-phenylethynyl]-3-nitro-phenylethynyl\}-phenylamine}

(5). Following the general coupling procedure $4(0.63 \mathrm{~g}, 2.36 \mathrm{mmol})$ was coupled to 3 (0.65 g, $2.14 \mathrm{mmol})$ using $\mathrm{PdCl}_{2}\left(\mathrm{PPh}_{3}\right)_{2}(0.08 \mathrm{~g}, 0.12 \mathrm{mmol}), \mathrm{CuI}(0.04 \mathrm{~g}, 0.21 \mathrm{mmol})$, TEA ( $3 \mathrm{~mL})$, and THF $(20 \mathrm{~mL})$. The reaction was stirred at room temperature overnight. The reaction was poured in $\mathrm{H}_{2} \mathrm{O}$ and extracted (3x) with $\mathrm{CH}_{2} \mathrm{Cl}_{2}$, dried using anhydrous $\mathrm{MgSO}_{4}$ and concentrated in vacuo. Column chromatography, silica gel $\left(\mathrm{CH}_{2} \mathrm{Cl}_{2}\right)$ afforded 5 as a yellow solid (0.50 g, 53\%). mp: $172-175{ }^{\circ} \mathrm{C}$; FTIR (KBr) 3496, 3390, $2972,2204,1619,1602,1538,1518,1393,1343,1302,1271,1099,844,829,530 \mathrm{~cm}^{-1}$. ${ }^{1} \mathrm{H}$ NMR $\left(400 \mathrm{MHz},\left(\mathrm{CD}_{3}\right)_{2} \mathrm{CO}\right) \delta 8.14(\mathrm{~d}, J=0.9 \mathrm{~Hz}, 1 \mathrm{H}), 7.77(\mathrm{~d}, J=2.9 \mathrm{~Hz}, 2 \mathrm{H}), 7.56$ $(\mathrm{d}, J=8.4 \mathrm{~Hz}, 2 \mathrm{H}), 7.5(\mathrm{~d}, J=8.5 \mathrm{~Hz}, 2 \mathrm{H}), 7.32(\mathrm{~d}, J=8.5 \mathrm{~Hz}, 2 \mathrm{H}), 6.71(\mathrm{~d}, J=8.5 \mathrm{~Hz}$, $2 \mathrm{H}), 5.21(\mathrm{~s}, 2 \mathrm{H}), 3.83(\mathrm{q}, J=8.1 \mathrm{~Hz}, 4 \mathrm{H}), 1.32$ (s, broad, $3 \mathrm{H}), 1.23$ (s, broad, $3 \mathrm{H}) .{ }^{13} \mathrm{C}$ NMR $\left(125 \mathrm{MHz},\left(\mathrm{CD}_{3}\right)_{2} \mathrm{CO}\right) \delta 153.1,150.9,150.6,135.7,135.3,134.1,133.5,127.3$, 125.8, 121.4, 119.0, 117.5, 114.9, 109.6, 99.5, 96.5, 85.60, 85.55. HRMS calcd for $\mathrm{C}_{26} \mathrm{H}_{23} \mathrm{~N}_{5} \mathrm{O}_{2} 437.1852$, found 437.1844 .

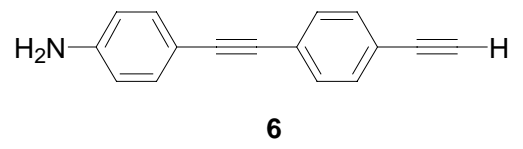

4-(4-Ethynyl-phenylethynyl)-phenylamine $\quad(6) .{ }^{9} \quad$ Following the general coupling procedure (4-iodo-phenylethynyl)-trimethyl-silane ${ }^{7}(0.75 \mathrm{~g}, 2.50 \mathrm{mmol})$ was coupled to 4-ethynyl-phenylamine ${ }^{8}(0.35 \mathrm{~g}, 3.00 \mathrm{mmol})$ using $\mathrm{PdCl}_{2}\left(\mathrm{PPh}_{3}\right)_{2}(0.09 \mathrm{~g}, 0.13 \mathrm{mmol})$, $\mathrm{CuI}(0.05 \mathrm{~g}, 0.25 \mathrm{mmol}), \mathrm{TEA}(3 \mathrm{~mL})$, and THF $(10 \mathrm{~mL})$. The reaction was stirred at 40 ${ }^{\circ} \mathrm{C}$ overnight. The mixture was poured in $\mathrm{H}_{2} \mathrm{O}$ and extracted (3x) with $\mathrm{CH}_{2} \mathrm{Cl}_{2}$, dried 
using anhydrous $\mathrm{MgSO}_{4}$ and concentrated in vacuo. Column chromatography, silica gel $\left(\mathrm{CH}_{2} \mathrm{Cl}_{2}\right)$ afforded 4-(4-trimethylsilanylethynyl-phenylethynyl)-phenylamine as a yellow solid $(0.64 \mathrm{~g})$. Following the general deprotection of TMS-protected alkynes, 4-(4trimethylsilanylethynyl-phenylethynyl)-phenylamine $(0.64 \mathrm{~g}, 2.21 \mathrm{mmol})$ was dissolved in a mixture of $\mathrm{CH}_{2} \mathrm{Cl}_{2}(15 \mathrm{~mL}), \mathrm{MeOH}(15 \mathrm{~mL})$, and $\mathrm{K}_{2} \mathrm{CO}_{3}(1.53 \mathrm{~g}, 11.05 \mathrm{mmol})$. The product 6 , was afforded without additional purification as an orange solid $(0.47 \mathrm{~g}, 87 \%, 2$ steps). ${ }^{1} \mathrm{H}$ NMR $\left(400 \mathrm{MHz},\left(\mathrm{CD}_{3}\right)_{2} \mathrm{CO}\right) \delta 7.45(\mathrm{~m}, 4 \mathrm{H}), 7.25(\mathrm{~d}, J=6.7 \mathrm{~Hz}, 2 \mathrm{H}), 6.68(\mathrm{~d}$, $J=6.7 \mathrm{~Hz}, 2 \mathrm{H}), 5.09(\mathrm{~s}, 2 \mathrm{H}), 3.77(\mathrm{~s}, 1 \mathrm{H})$.

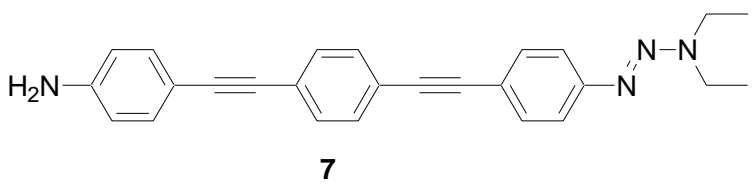

\section{4-\{4-[4-(3,3-Diethyl triazene)-phenylethynyl]-phenylethynyl\}-phenylamine (7).}

Following the general coupling procedure $6(0.48 \mathrm{~g}, 2.21 \mathrm{mmol})$ was coupled to $3(0.61$ $\mathrm{g}, 2.01 \mathrm{mmol})$ using $\mathrm{PdCl}_{2}\left(\mathrm{PPh}_{3}\right)_{2}(0.07 \mathrm{~g}, 0.10 \mathrm{mmol})$, CuI (0.04 g, $\left.0.20 \mathrm{mmol}\right)$, TEA (5 $\mathrm{mL})$, and THF $(20 \mathrm{~mL})$. The reaction was stirred at room temperature for $1 \mathrm{~h}$ until the starting material was consumed as judged by TLC. The mixture was poured in $\mathrm{H}_{2} \mathrm{O}$ and extracted (3x) with $\mathrm{CH}_{2} \mathrm{Cl}_{2}$, dried using anhydrous $\mathrm{MgSO}_{4}$ and concentrated in vacuo. The residue was dissolved in a minimum amount of $\mathrm{CH}_{2} \mathrm{Cl}_{2}$ followed by the addition of hexane. The $\mathrm{CH}_{2} \mathrm{Cl}_{2}$ was carefully removed in vacuo and the precipitate was collected using vacuum filtration to afford 7 as a pale solid $(0.62 \mathrm{~g}, 79 \%)$. mp: $169-173{ }^{\circ} \mathrm{C}$; FTIR (KBr) 3463, 3371, 2973, 2932, 2208, 1618, 1599, 1519, 1396, 1339, 1291, 1237, 1095, 836, $529 \mathrm{~cm}^{-1} .{ }^{1} \mathrm{H}$ NMR $\left(500 \mathrm{MHz},\left(\mathrm{CD}_{3}\right)_{2} \mathrm{CO}\right) \delta 7.52(\mathrm{~d}, J=6.9 \mathrm{~Hz}, 2 \mathrm{H}), 7.48(\mathrm{~d}, J=$ $6.9 \mathrm{~Hz}, 2 \mathrm{H}), 7.42(\mathrm{~d}, J=6.8 \mathrm{~Hz}, 2 \mathrm{H}), 7.26(\mathrm{~d}, J=6.8 \mathrm{~Hz}, 2 \mathrm{H}), 6.68(\mathrm{~d}, J=6.8 \mathrm{~Hz}, 2 \mathrm{H})$, 
$5.20(\mathrm{~s}, 2 \mathrm{H}), 3.83(\mathrm{q}, J=5.6 \mathrm{~Hz}, 4 \mathrm{H}), 1.31$ (s, broad, $3 \mathrm{H}), 1.22$ (s, broad, $3 \mathrm{H}) .{ }^{13} \mathrm{C}$ NMR $\left(100 \mathrm{MHz},\left(\mathrm{CDCl}_{3}\right) \delta 151.3,147.0,133.2,132.5,131.6,131.4,125.0,123.7,123.0\right.$, 120.6, 119.4, 115.0, 112.6, 92.2 91.9, 89.3, 87.5. HRMS calcd for $\mathrm{C}_{26} \mathrm{H}_{24} \mathrm{~N}_{4}$ 392.2001, found 392.2011.

\section{References}

1. Stewart, M. P.; Maya, F.; Kosynkin, D. V.; Dirk, S. M.: Stapleton, J. J.; McGuiness, C. L.; Allara, D. L.; Tour, J. M. J. Am. Chem. Soc. 2004, 126, 370-378.

2. Dyke, C. A.; Tour, J. M. Nano Lett. 2003, 3, 1215-1218.

3. O'Connell, M. J.; Bachilo, S. M.; Huffman, C. B.; Moore, V. C.; Strano, M. S.; Haroz, E. H.; Rialon, K. L.; Boul, P. J.; Noon, W. H.; Kittrell, C.; Ma, J.; Hauge, R. H.; Weisman, R. B.; Smalley, R. E. Science 2002, 297, 593.

4. Sonogashira, K.; Tohda, Y.; Hagihara, N. Tetrahedron Lett. 1975, 50, 4467.

5. Holmes, B. T.; Pennington, W. T.; Hanks, T. W. Synth. Commun. 2003, 33, 2447 2462.

6. Flatt, A. K.; Yao, Y.; Maya, F.; Tour, J. M. J. Org. Chem. 2004; 69, 1752-1755.

7. Maya, F.; Flatt, A. K.; Stewart, M. P.; Shen, D. E.; Tour, J. M. Chem. Mater. 2004 16, 2987-2997.

8. Fan, F. R.; Yang, J.; Cai, L.; Price, D. W.; Dirk, S. M.; Kosynkin, D. V.; Yao, Y.;

Rawlett, A. M.; Tour, J. M.; Bard, A. J. J. Am. Chem. Soc. 2002, 124, 5550.

9. Lavastre, O.; Cabioch, S.; Dixneuf, P. H.; Vohlidal, J. Tetrahedron, 1997, 53, 7595 7604. 
